\title{
The Socioeconomic Determinants of Crime in Pakistan
}

\author{
Muhammad Umair \\ Department of Business Administration \& Commerce, University Of Sargodha, Sargodha, Punjab, Pakistan \\ mumair342@yahoo.com
}

\begin{abstract}
Crime is one of the major issues in Pakistan. It not only affects our society but also our economy. The main purpose of this study is showing the effects of socio-Economic factors such as Inflation, Population, income and economic growth to crimes. For this purpose we use secondary data and collected from Pakistan Bureau of Statistics and World Bank over 2006 to 2016. Correlation and regression analysis use to check the socio-economic effects on crimes. Results show negative relation of crime and economic growth. Government strives on economic growth, because it improves, crimes reduce gradually.
\end{abstract}

Keywords : crimes; socio-economic factors; economic growth; correlation; regression

\section{Introduction}

Criminal activities have immensely affected on economic activities. Diaw, Lobont, \& Moldovan, [2014] shows the relation ship between economic condition and crime. Crimes always create harmful disaster for society. In other sense, crime means simply anti-social activities which create disturbance in society. Financial crime started with Becker [1968] invstigation, which create the link with criminology [Buonanno, 2003].

Merton [1938] proposed that crimes set the goals of financial satisfaction. Some researchers indicate that distribution of wealth unfairly leads the crimes [Brush, 2007]. The scenario of one country is differ to other country. So Alexandros [2010] say that crime consistantly rise in develop and eurpion nations, the agenda behind are financial benefits by chosing the legal and antilegal stratgies.

According to above descussion we can say that illegal finanial gain is one of the prominent factor of crime. It can be mediate by understanding the behavior of individual. This study shows the relationship of crimes with inflation and houshold income of Pakistan prospective.

According to Khan, Ahmed, Nawaz, \& Zaman [2015] study, crime growth rate in 1958 was 6.02, in 1961, crime growth rate deciline at-1.51. but it increase positivly except in 1981 and 2000 where crime growth rate was -8.53 and -9.94 respectviely. Their findings show the negative relation of education but the education of over earning can lead to crimes in pakistan. Morever there is direct relation between crimes and poverty. Now present study shows the relationship of crime with inflation, economic growth and houshold income over 2006-2015.

The debate on the relation of crimes with economic activies is limited due to some kinds of confusion [Ishikawa, 2009]. But the study of Kustepli, [2006] edovear to take more illegal financial activites with the context of crimes. Increasing crime rate has creates serious problem for all the stakholders in pakistan. So, the contentions points of this study are litratrue review, methodology, result and conclusion respectively.

\section{Review of Literature}

There are immunesly litrature available for explaining the econominc factors leads to crimes in all over the world. Becker [1968] and Ehrlich [1973] work shows the more crime accur due to financial matters and unemployement. According to them, when individual income decrease financial situation is adverse over the ordinary time and this situation 
adversaly affect on the society and thus, crime increase. Corman [1987] studies the relationship among social,economic, administrative and personal related crimes. Result shows not as strong connection between unemployement and crimes. But, social variable is closely connected with crimes in new York.

Elliot [1992] conduct study by using primary data for checking British crime with respect to unemployement. Regratission analysis prove the positive relation of unemployement and crimes in Britsh. Entrof [1998] shows the crime rate in germany and conclude that demographic factors contribute in crimes. According to study, East germany is more vulnarable than west germony due to income effect. Cerro \& Meloni [2000] conduct research in argentina and conclude that, income level and unemployement have strongly associate with crime rate in argentina.

Fajnzylber, Laderman, \& Loayza [2002] examine over 39 countries by taking income inequality as a variable and conclude that, income inequality and crime rates are strongly associated with each other. Gumus [2004] check the crime rate and its relation with urbanlization by choosing simple correlation and regression. Analysis shows that,economic factors such as income and per capita income are play an important role in crime rates of United State of America. Buonanno [2003] check the relationship of education and crime in Italian religos and prove that there are adverse relationship of variables.

Saridakis [2004] say that there are no such a long relationship between socio - economic factor and crimes, but in short run, it can affect on crime. According to Edmark [2005] opinion, unemployement has vast contribution in crimes and show the positive connection between the variables. Buonanno \& Montolio [2008] say that governament policies and ambasidors have positive link with crime rates in spanish. According to Baharom \& Habibullah [2009] there is no such a long time relation between variables So, according to above studies, income is one of the more prominent factor which affect on crime.

Lobonţ, Nicolescu, Moldovan, \& Kuloğlu [2017] explain the inflation and economic growth are important ingrediants of crime.

Alexandros [2010] also show the inverse relation between economic crisis and crime rate. In case of Boom crimes rate are decrease, but in depression days the probability of crime increase as compare to ordinory days. So according to above studies, income is one of the more prominent factor which affect on crime. this study not only check the relation ship between income and crime but also investgate the relationship between inflation and economic growth with the context of crimes. Because when inflation increase, its affect on the purchasing power of individual so the new hypothesis generated that inflation has positive relation with crimes.

\subsection{Data collection}

\section{Method}

This study covers the data for the period of 2006-2016. Data collected from secondary sources which was available related to study. Data related to crimes is take from Pakistan bearu of Statistics, and data related to Inflation, economic growth, Population and National income take from world bank.

Crime rates can be find by using following equation

Crime Rate $=\frac{\text { T.C. } R}{\mathrm{~N}} * 10000$

$\mathrm{N}$

T.C.R $=$ Total Crimes Reported

$\mathrm{N} \quad=$ Population [10000 per]

DOI : https://doi.org/10.33258/birci.v2i3.387 
Table 1. Data use in this study

\begin{tabular}{|l|l|l|l|l|l|}
\hline & Crime & Population & Net Income & Inflation & $\begin{array}{l}\text { GDP } \\
\text { per capita } \\
\text { growth }\end{array}$ \\
\hline 2006 & 33.36455 & 2.047845535 & 6.197956809 & 7.921084 & 4.025302468 \\
\hline 2007 & 32.69496 & 2.040843253 & 3.323912392 & 7.598684 & 2.715027687 \\
\hline 2008 & 35.285 & 2.044428121 & 4.708225462 & 20.28612 & -0.356696773 \\
\hline 2009 & 36.88887 & 2.05936331 & -0.02874204 & 13.64777 & 0.735637493 \\
\hline 2010 & 38.3022 & 2.079755347 & 6.077033111 & 13.88114 & -0.484655809 \\
\hline 2011 & 38.6803 & 2.102552508 & 3.113748187 & 11.91677 & 0.610616229 \\
\hline 2012 & 36.36077 & 2.1172688 & 4.370521609 & 9.685053 & 1.338548629 \\
\hline 2013 & 34.91249 & 2.113986943 & 2.729039553 & 7.689504 & 2.212692738 \\
\hline 2014 & 33.79836 & 2.087792429 & 4.705752968 & 7.191671 & 2.511972625 \\
\hline 2015 & 33.45645 & 2.045407255 & 6.114417354 & 2.539516 & 2.610728514 \\
\hline 2016 & 35.06945 & 1.998562594 & 6.313411588 & 3.752596 & 3.384636674 \\
\hline
\end{tabular}

\subsection{Theoretical framework}

In this study, according to Lobonţ, Nicolescu, Moldovan, \& Kuloğlu [2017]we use one dependent variable [crimes] and remaining are independent variables [Population growth, net income, inflation and economic growth.

Based on our data we can define as:

crime $=\mathrm{f}$ [Population, Net National Income, Inflation, Economic growth]

And for regrression $\quad \mathrm{Y}=\mathrm{a}+\mathrm{bX}$

\subsection{Methadology}

According to our purpose we use simple methadology which was adopted by Elliot [1992] and Gumus [2004].

So in this study we will use correlation and Regression analysis which are easily use and understandable. Following equations are use for correlation and regression respectively.

\section{Discussion}

Table 2. Correlation

\begin{tabular}{|c|c|c|c|c|c|}
\hline & Crime & Population & $\begin{array}{l}\text { Net } \\
\text { Income }\end{array}$ & Inflation & $\begin{array}{l}\text { GDP } \\
\text { per } \\
\text { capita } \\
\text { growth }\end{array}$ \\
\hline Crime & 1 & & & & \\
\hline Population & 0.423441 & 1 & & & \\
\hline Net Income & -0.26626 & -0.34427 & 1 & & \\
\hline Inflation & 0.53414 & 0.198655 & -0.32639 & 1 & \\
\hline $\begin{array}{l}\text { GDP per capita } \\
\text { growth }\end{array}$ & -0.75953 & -0.35968 & 0.298991 & $\begin{array}{l}- \\
0.83678\end{array}$ & 1 \\
\hline
\end{tabular}


Above table shows the correlation between all variables. According to analysis, there is positive correlation between crime and population growth. Net income and crime see to be negative correlation, there is also negative correlation between net income and population growth, according to analysis, we show positive correlation between inflation, crimes and population. GDP of per capita growth showing negative relation with respect to crimes and population. But, shows positive correlation net income and inflation rate of Pakistan.

Table 3. Regression Statistics

\begin{tabular}{|l|l|}
\hline Multiple R & 0.792593 \\
\hline R Square & 0.628204 \\
\hline Adjusted R Square & 0.380341 \\
\hline Standard Error & 1.583293 \\
\hline Observations & 11 \\
\hline
\end{tabular}

Above table shows the Multiple R shows the data put on the regression line, so 0.628204 data come on the line. Adjusted R square show the result after adjusting all the probabilities. Standard error value shows 1.58 in the table of 11 observations.

Table 4. Anova

\begin{tabular}{|l|l|l|l|l|l|}
\hline & df & SS & MS & F & Significance F \\
\hline Regression & 4 & 25.41384 & 6.353461 & 2.534474 & 0.148252 \\
\hline Residual & 6 & 15.0409 & 2.506816 & & \\
\hline Total & 10 & 40.45474 & & & \\
\hline
\end{tabular}

Anova table shows regression results and residual values with respect to degree of freedom, sum of square and Means Square. Moreover $f$ test shows the 2-53 value $5 \mathrm{f}$ square of both regression and residual value are 40.45474 .

Table 5. Coefficients

\begin{tabular}{|l|l|l|l|l|l|l|l|l|}
\hline & Coefficients & $\begin{array}{l}\text { Standard } \\
\text { Error }\end{array}$ & $t$ Stat & P-value & $\begin{array}{l}\text { Lower } \\
95 \%\end{array}$ & $\begin{array}{l}\text { Upper } \\
95 \%\end{array}$ & $\begin{array}{l}\text { Lower } \\
95.0 \%\end{array}$ & $\begin{array}{l}\text { Upper } \\
95.0 \%\end{array}$ \\
\hline Intercept & 24.46571 & 33.9075 & 0.721543 & 0.497717 & -58.5029 & 107.4344 & -58.5029 & 107.4344 \\
\hline Population & 7.001788 & 15.72936 & 0.445141 & 0.671827 & -31.4866 & 45.49015 & -31.4866 & 45.49015 \\
\hline Net Income & -0.03649 & 0.285629 & -0.12775 & 0.902524 & -0.7354 & 0.66242 & -0.7354 & 0.66242 \\
\hline Inflation & -0.12112 & 0.189233 & -0.64007 & 0.545779 & -0.58416 & 0.341915 & -0.58416 & 0.341915 \\
\hline $\begin{array}{c}\text { GDP per } \\
\text { capita growth }\end{array}$ & -1.29118 & 0.658747 & -1.96006 & 0.097688 & -2.90308 & 0.320715 & -2.90308 & 0.320715 \\
\hline
\end{tabular}

According to above table, crime and population shows the positive relation and net income, inflation and per capita growth shows the negative relation with respect to crimes. $\mathrm{T}$ test of all variables are less than 2 except GDP per capita growth and $\mathrm{p}$ value also show the significance relationship between GDP and crimes. So above result prove that there is negative relation between GDP per capita growth and crimes. 


\section{Conclusion}

The main purpose of this study is to find the relationship of socio-economic factors. In this study dependent variable was crime rate and independent variables were population growth, inflation, national income and economic growth.

So here we reject the [Cerro \& Meloni 2000] and accept the Gumus [2004] and Saridakis [2004] results, because crime and economic growth has strong relation between them, population has positive relation with crime and inflation and income has negative relations in short run. Due to $t$ value which is less than 1.9 and $p$ value shows more than 0.05 of all variables except economic growth. So we can say there are no long run relationships of inflation, national income and population but economic growth. Economic growth shows the inverse relation with crime. So, when the crime increase economic growth declines this is unfavorable situation for the country.

So, we can minimize this curse by adopting appropriate strategy for economic growth.

\section{References}

Alexandros, G. \&. [2010]. The effect of socio-economic determinants on crime rates: An empirical research in the case of Greece with co integration analysis. International journal of Economic Science and Applied Research, 2: 2, 51-64.

.Baharom, H. A., \& Habibullah, S. M. [2009]. Crime and inequality: The case of Malaysia. Journal of Politics and Law, 2:1, 55-70.

.Becker, G. S. [1968]. Crime and Punishment: An Economic Approach. Journal of Political Economy, 76: 2, 169-217.

.Brush, J. [2007]. Does income inequality lead to more crime? A comparison of Cross-sectional and time-series analysis of United States counties. Economics letters, 96, 264-268.

.Buonanno, P. [2003]. Identifying the Effect of Education on Crime. Evidence from the Italian Regions. Università degli Studi di Milano - Bicocca No.65.

Buonanno, P. [2003]. Identifying the Effect of Education on Crime. Evidence from the Italian Regions. Università degli Studi di Milano - Bicocca No.65.

.Buonanno, P., \& Montolio, D. [2008]. Identifying the socio-economic and demographic determinants of crime across Spanish provinces. International review of Law, 28, 89-97.

Cerro, M. A., \& Meloni, O. [2000]. Determinants of crime rate in Argentina during the 90's. Estudious de economia, 27: 2, 297-311.

Corman, H. J. [1987]. Crime, Deterrence and the business cycle in New York City: A VAR approach. The review of economics and statistics, , 697-700.

Diaw, A., Lobonţ, O. R., \& Moldovan, N. C. [2014]. Some relevant risk factors and causal mechanisms to understand crime in Romania. Review of Applied Socio-Economic Research, 8, 64-69.

Edmark, K. [2005]. Unemployment and Crime: Is There a Connection? Scandinavian Journal of Economics, 107:2, 353-373.

Ehrlich, I. [1973]. Participation in illegitimate activities: A theoretical and empirical investigation. The Journal of Political Economy, 81:3, 307-322. 
Elliot, C. \&. [1992]. The relationship between unemployment and crime: A cross-sectional analysis employing the British Crime Survey 1992. International journal of manpower, 16: $6 / 7,81-88$.

Entrof, H. \&. [1998]. Socio-Economic and demographic factors of crimes in Germany: Evidence from panel data of the German states. International Review of Law and Economics, 20 [1], 75-106.

Fajnzylber, P., Laderman, D., \& Loayza, N. [2002]. Inequality and violent crimes. Journal of Law and Economics, XLV, 1-40.

Gumus, E. [2004]. Crime in urban areas: An empirical investigation. Akdeniz I.I.B.F. Dergisi, 4 [7], 98-109.

Ishikawa, M. [2009]. A relationship between economic conditions and crime rate. online available.

Khan, N., Ahmed, J., Nawaz, M., \& Zaman, K. [2015]. The Socio-Economic Determinants of Crime in Pakistan: New Evidence on an Old Debate. Arab Economics and Business Journal 10, 73-81.

Kustepli, Y. G. [2006]. Different Categories of Crimes and their Socio-Economic determinants in Turkey: Evidence from the Vector Error Correction model. http://www4.ncsu.edu/ gonel/docs/crime_kustepeli_onel.pdf.

Lobonţ, O.-R., Nicolescu, A.-C., Moldovan, N.-C., \& Kuloğlu, A. [2017]. The effect of socioeconomic factors on crime rates in Romania: a macro-level analysis. Economic REsEaRch-Ekonomska istRaživanja, 91-111.

Merton, R. [1938]. Social Structure and Anomie. American Sociological Review, 3:6, 72-82.

Saridakis, G. [2004]. Violent crimes in the United States of America: A time series analysis between 1960-2000. Discussion Papers in Economics:

http://www.le.ac.uk/economics/research/discussion/papers2003.html. 